\title{
Human dignity and ethical treatment: Remarks on family concepts and family life in the era of the Reformation
}

\begin{abstract}
Martin Luther and the Reformation movement placed the household family anew at the centre of Christian life and ethics. In the wider sphere this religious "upgrading" cannot be overestimated in view of its effect on the process of confessionalization and modernization in European history. The education of children held a prominent place within the responsibilities of the household family; it was regarded as a divine task. Through this the Reformation movement intensified and specified humanist endeavours, which Erasmus summarized with the words: Human beings, believe me, are not born, but formed. Steven Ozment once maintained, that the family of the 16 th century was a nurturing institution, characterized by love, respect and mutual dependence among the members of the family.
\end{abstract}

It is with good reason that Biblical scholars stress the necessity of contextualizing New Testament texts on the family within the framework of Greco-Roman culture. One has principally to consider the variety of attitudes and values attached to family terminology and the metaphorical usage of such descriptions. In particular the inner tension between consistent discipleship and social reality demonstrates that an ethical task had to be accomplished. There are no standard answers to the question of what is meant precisely by human dignity and ethical treatment in this context. In historical studies, and therefore also in Church history, the reconstruction of family concepts and family life still is a challenging endeavour. Biblical exegesis has to be enriched with perspectives derived from historical development within Christian communities through the centuries. The following remarks are an attempt to summarize and reflect on some aspects of family history at the time of the Reformation. ${ }^{1}$

From New Testament contexts we learn, that the basic societal unit was not the private modern nuclear family, but the so-called "Oikos" or household, which may also be called "household family". This organism incorporated a wide range of personal relationships, economic necessities and kinship. With some variations the household family remained the dominant pattern in the social reality of pre-modern Western societies. However, neither the theory nor the reality of the household family were as simplistic, as sometimes suggested. One may, for example, deplore the damage done by the church's endorsement of patriarchal, sexist and marginalizing forms

\footnotetext{
1 For the following remarks see especially Ozment, SE 1983, When Fathers Ruled. Family Life in Reformation Europe, Cambridge Mass.: Harvard Univ. Press; Ozment, SE 2001, Ancestors. The Loving Family in Old Europe, Cambridge, Mass.: Harvard Univ. Press; Forster, MR \& Kaplan, BJ (eds) 2005, Piety and Family in Early Modern Europe. Essays in Honour of Steven Ozment, Aldershot, Hants: Ashgate; van Dülmen, R 1990, Kultur und Alltag in der frühen Neuzeit, München: Beck, vol 1: (4th edn 2005), Das Haus und seine Menschen. 16. - 18. Jahrhundert; Duby, G \& Perrot, M (eds.) 2006, Geschichte der Frauen, vol 3: Frühe Neuzeit, ed A. Farge, N.Z. Davis, Frankfurt/Main: Zweitausendeins; Holzem, A \& Weber, I (eds) 2008, Ehe - Familie - Verwandtschaft. Vergesellschaftung in Religion und sozialer Lebenswelt, Paderborn: Schöningh; Schmidt-Voges, I (ed) 2010, Ehe - Haus - Familie. Soziale Institutionen im Wandel 1750-1850, Köln: Böhlau.
} 
of family life over many centuries. But this sort of generalization could also be applied to the New Testament itself. A discussion on the place of dignity and violence in the history of family is at least as complicated as the debate on New Testament texts, and every context ought to be evaluated on its own terms. ${ }^{2}$

Martin Luther and the Reformation movement placed the household family anew at the centre of Christian life and ethics. In the wider sphere this religious "upgrading" cannot be overestimated in view of its effect on the process of confessionalization and modernization in European history. For all members of the household family a specific set of ethical commitments was worked out, on the basis of a spiritual equality coram Deo (in the presence of God). This was done in the context of catechetical literature, following the Ten Commandments, but also in literature on Christian behaviour, the so-called housefather- and housemother-literature. Naturally the household family was patriarchal and gender-constructed, but in contemporary eyes it was in no way per se repressive. Even in pre-modern times theory and practice had engendered their own dynamics: what was intended to stabilize the feudal system, cannot be separated from the ongoing process of rethinking and reorganizing ethical treatment and human dignity "in context". One of the more obvious places to study these dynamics is the history of education. The education of children held a prominent place within the responsibilities of the household family; it was regarded as a divine task. Through this the Reformation movement intensified and specified humanist endeavours, which Erasmus summarized with the words: Human beings, believe me, are not born, but formed - homines, mihi crede, non nascuntur, sed finguntur. ${ }^{3}$ We may say then that human dignity in modern contexts is based on individual rights, but in pre-modern contexts it was based on common obligations, specified by different "offices" in a divine order of family, kinship, and political authority, and defined by status, generation, kin affiliation and rank.

In the past pre-modern family life was often interpreted as hostile to the development of emotional relationships among its participants (L. Stone, Ph. Ariès). However, as a closer look on the sources shows us, there was more love, practical equality and mutual respect than might be expected. Had this not been so, the tensions between familial and religious loyalties would be more difficult to explain. Family ties often remained stronger than religious commitments, as we can see in the context of conversion stories and changing confessional identities, where the unity of the family and the right handling of common property was at stake.

Although there was no formal equality, in the daily life of middle-class women there was quite a high degree of team-work and cooperation at all levels of the household. Women were active partners in economic affairs. One famous example is M. Luther's wife Katharina, who was known for brewing a good beer, and who continued with her entrepreneurial activity after the death of her husband. Formal inequality was not the same as submission.

In the realm of political science and social theory the concept of the household family played an important role as an "ideal type" (cf. Max Weber's "Idealtypus"). The Aristotelian "Oikos" had already been adapted in the Middle Ages to the specific necessities of Christian society, by the concept of the Oeconomia christiana. In the Oeconomia christiana literature, which became well-known in the $16^{\text {th }}$ and $17^{\text {th }}$ centuries, personal relationships and economic management were regulated together in a combination of personal and social ethics. ${ }^{4}$ The household

2 For perspectives from New Testament scholarship cf. Barton, SC 1996, 'Towards a Theology of the Family' in Christian Perspectives on Sexuality and Gender, eds E.Stuart \& A Thatcher, Grand Rapids: Eerdman, 451-462. Barton, SC 2001, Life Together. Essays on Family, Sexuality and Community in the New Testament and Today, Edinburgh: T\&T Clark.

3 Erasmus, D 1971, 'De pueris instituendis' in Opera omnia (=ASD) I-2, Amsterdam: Elsevier, 1-78; 31.21 .

4 Cf. Menius, J (1529), Oeconomia christiana, Wittenberg: Lufft; Coler, J 1593-1604, Oeconomia Oder 
functioned as the cradle of responsible citizenship, and was oriented to the common good. The fact that its patriarchal structure was legitimated theologically - God functioned as housefather of the universe - naturally evokes critical evaluation. This, however, should not prevent us from realizing the inherent dynamics, on the basis of which practical behaviour could be negotiated. And it should not prevent us from asking what, for example, Luther's concept of the three "offices" of a Christian or his participation in the three "estates" contributed to the reality of human dignity in his time, and what it probably can contribute to our own understanding of it.

For Luther the individual did not exist apart from state or society. His perspective was directed to everybody's participation in three "estates" or relationships at the same time. Besides priesthood (the priesthood of all believers) and political authority ("weltliche Obrigkeit") came the household family or marriage, as a social institution. It is noteworthy that Luther placed "Christian love" above these three estates. ${ }^{5}$ Obviously he felt the need for a superior normative value to secure responsibility and ethical treatment. Here the constant interest in a good education for the children at home and in public institutions had its roots. Parenting was regarded as a rational art and the exercise of authority, in analogy to God's parental role towards mankind. According to Luther, there was no power on earth that was nobler or greater than that of parents. The diligent rearing of children was seen as the greatest service to the world, both in spiritual and temporal affairs. Parents who fell short in the task of rearing their children, according to Luther should be publicly punished or even forced to leave the country. ${ }^{6}$ Although this was far from reality, it shows us, that the housefather's authority was in no way regarded as being independent.

Indeed, the main purpose of bringing up children was to educate God-fearing, obedient and virtuous Christians and citizens. This was a joint task for mother and father, the latter becoming more important when the child was aged six or seven and regarded as being able to respond to regular discipline. Those who brought up their children according to God's commandments, taught them self-discipline, self-respect and a sense of honour successfully, could be relied upon to have treated them with dignity, and to have educated good citizens. In the "Christian economy" parents were admonished to avoid too harsh a treatment of their children, for example by demanding hard work from them in early childhood, or by intimidating them too much by physical punishment. Moderate corporal punishment was seen as normal, at home and at school. Horror stories about extreme physical punishment (J. Butzbach) surely do not describe reality in general. As in the wisdom literature in Antiquity, in the Bible and Early Church sources a classical middle way between measured threats and parental love was regarded to be the best educational method. Indeed the fear of anarchy and criminality was often greater than the fear of misusing parental power.

In a patriarchal society the education of girls was mostly regarded as less important, but it never was totally neglected. At least since Reformation times girls also had to follow a basic educational programme, partly in public schools, where female teachers also worked.

The high esteem of the household family also was expressed in the definition of the household as a "church". According to Luther parents exercised religious "offices", as an apostle, bishop or pastor. So it is not surprising, although unusual, that Luther in his famous preface to the German Mass (1526) suggested a special way of organizing Christians in house churches. Those, who wanted to intensify their spiritual life alongside public worship ("die mit Ernst Christen sein

Haußbuch [...] Darinnen begriffen [...] ist, Wie ein jeder Haußwirth [...] seine Nahrung, nechst Gott anstellen sol, auch fruchtbarlichen geniessen und gebrauchen, 6 vols, Wittenberg: Helwich; later editions were published under the standard title Oeconomia ruralis et domestica.

5 Cf. WA 26, 504.

6 WA $30 / 2,61$. 
wollen") were encouraged to study the Bible, to celebrate the sacraments and to practise acts of Christian love - in the framework of the household family. ${ }^{7}$ This idea has stimulated Church reform movements within the Protestant tradition through the centuries.

It is important to see, that the concept of the patriarchal household family was an idealization of the social reality. The main focus was the middle-class family of peasants, craftsmen or inhabitants of the cities (those who owned some property). No separate "Christian economy" was developed for the lower classes, which included many single women, or for the nobility. This may be interpreted as a blind spot in Christian middle-class ethics, but it also may be seen as a common ideal of a society, where extreme poverty and wealth had no place.

Steven Ozment once maintained, that the family of the 16th century was a nurturing institution, characterized by love, respect and mutual dependence among the members of the family. Perhaps this assertion sounds one-sided, given the number of specific legal restrictions and problematic social imbalances within pre-modern society. It is nevertheless remarkable, that a well-known historian could describe the family of the past in terms such as we would be happy to see realized today. This should encourage us to discuss more often themes such as human dignity with respect to their relationship to past reality, both in social and theological contexts.

\section{BIBLIOGRAPHY}

Barton, SC 2001, Life Together. Essays on Family, Sexuality and Community in the New Testament and Today, Edinburgh: T\&T Clark.

Barton, SC 1996, 'Towards a Theology of the Family' in Christian Perspectives on Sexuality and Gender, eds E.Stuart \& A Thatcher, Grand Rapids: Eerdman, 451-462.

Coler, J 1593-1604, Oeconomia Oder Haußbuch [...] Darinnen begriffen [...] ist, Wie ein jeder Haußwirth [...] seine Nahrung, nechst Gott anstellen sol, auch fruchtbarlichen geniessen und gebrauchen, 6 vols, Wittenberg: Helwich.

Duby, G \& Perrot, M (eds.) 2006, Geschichte der Frauen, vol 3: Frühe Neuzeit, ed. A. Farge, N.Z. Davis, Frankfurt/Main: Zweitausendeins.

Erasmus, D 1971, 'De pueris instituendis' in Opera omnia (= ASD) I-2, Amsterdam: Elsevier, 1-78.

Forster, MR \& Kaplan, BJ (eds) 2005, Piety and Family in Early Modern Europe. Essays in Honour of Steven Ozment, Aldershot, Hants: Ashgate.

Holzem, A \& Weber, I (eds) 2008, Ehe - Familie - Verwandtschaft. Vergesellschaftung in Religion und sozialer Lebenswelt, Paderborn: Schöningh.

Luther, M 1883-2000, Werke. Kritische Gesamtausgabe (= WA), Weimar: Böhlau (Nachf.) (Repr. 2000-2007). Menius, J (1529), Oeconomia christiana, Wittenberg: Lufft.

Ozment, SE 1983, When Fathers Ruled. Family Life in Reformation Europe, Cambridge Mass.: Harvard Univ. Press.

Ozment, SE 2001, Ancestors. The Loving Family in Old Europe, Cambridge, Mass.: Harvard Univ. Press. Schmidt-Voges, I (ed) 2010, Ehe - Haus - Familie. Soziale Institutionen im Wandel 1750-1850, Köln: Böhlau. van Dülmen, R 1990, Kultur und Alltag in der frühen Neuzeit, Beck, München, vol 1 (4th edn 2005) Das Haus und seine Menschen. 16. - 18. Jahrhundert, München: Beck.

\section{KEY WORDS}

Human dignity

Reformation

Violence

family life

ethics
Contact details:

Prof Hans-Martin Kirn

Professor of Church History

Protestant Theological University

The Netherlands

hmkirn@pthu.nl 